\title{
A New Approach to Calculate the Water Exploitation Index $\left(\mathrm{WEI}^{+}\right)$
}

\author{
Stefano Casadei ${ }^{1, *(D)}$, Francesco Peppoloni ${ }^{2}$ and Arnaldo Pierleoni ${ }^{2}$ \\ 1 Department of Civil and Environmental Engineering, University of Perugia, 06123 Perugia, Italy \\ 2 Engineering Department, Niccolò Cusano University, 00166 Roma, Italy; francesco.peppoloni@unipg.it (F.P.); \\ arnaldo.pierleoni@unicusano.it (A.P.) \\ * Correspondence: stefano.casadei@unipg.it
}

Received: 22 September 2020; Accepted: 16 November 2020; Published: 18 November 2020

\begin{abstract}
The Water Exploitation Index (WEI), or withdrawal ratio, is an indicator of water scarcity, which has been updated into its $\mathrm{WEI}^{+}$form by the Committee of Experts of the European Commission. In calculating the total abstraction of fresh water, this indicator also includes the possible return flow and management rules. The demand for freshwater and long-term freshwater resources are both necessary to calculate the $\mathrm{WEI}^{+}$. These values are not easy to assess at basin or sub-basin level and, for this reason, WEI values are generally calculated at the country level. This paper introduces a new approach to calculate the $\mathrm{WEI}^{+}$, with the purpose of extending its use to basin and sub-basin levels. The methodology is based on flow duration curve estimation, which evaluates freshwater resources, and a Web-GIS system that evaluates water abstractions distribution. This approach allows for the assessment of locally stressed areas in the hydrographic network and could provide a fundamental step toward more comprehensive regional water resources management plans. The new methodology is tested in some sub-basins of the Upper Tiber River Basin (Italy). These results contribute to the analysis of water withdrawals sustainability, based on the policy of the European Environment Agency, which is aimed toward the development of a proactive approach for reducing water stress.
\end{abstract}

Keywords: water scarcity indices; flow duration curve; water abstractions; Web-GIS; regionalization technique

\section{Introduction}

The $\mathrm{WEI}^{+}$was introduced by the Water Scarcity and Drought Expert Group of the European Commission within its set of common indicators for water scarcity and drought [1].

In recent years, several indicators have been developed to summarize the different characteristics of these two phenomena [2,3]. First of all, with regard to drought, it must be noted that its indicators generally represent weather and climate conditions. The Standardized Precipitation Index (SPI) [4] is a very common drought index, which compares the total precipitation collected during a period of $n$ months with the long-term rainfall distribution for the same period of time. It has also been adopted in the European Commission document [1], and it has several applications across the globe at different spatial and temporal scales. Reviews of the latest scientific literature have shown the applications of SPI at country [5-7] and regional [8-11] levels. With regard to SPI, it is possible to find updated regional values online; for example, the Massachusetts Drought Management Task Force [12] of the State of Massachusetts has displayed the SPI up until last month, as well as the Meteorological Department for the Indian region [13]. The same statistical approach for SPI can be adopted for the calculation of the Standardized Precipitation Evapotranspiration Index (SPEI) [14]. The SPEI can also be considered a climate indicator, which normalizes anomalies in accumulated climatic water balance, which is defined as the difference between precipitation and potential evapotranspiration. SPEI is usually aimed at understanding the impact of drought on agricultural ecosystem [15-17]. 
Another common type of drought indicator requires runoff data. In the analysis of hydrological drought, the Standardized Runoff Index (SRI), proposed by Shukla and Wood [18], and the Water Stress Index (WSI), developed by Pfister et al. [19], are the most commonly adopted indices. Employment of the SRI only requires runoff datasets and the application of the SPI concept to these data $[20,21]$. Zou et al. [22] developed a time-dependent SRI (SRI $\left.I_{v a r}\right)$ by considering the non-stationarity of a runoff series under changing environmental conditions. Yuan et al. [23] used the Standardized Streamflow Index (SSI), in which streamflow is used instead of runoff, in order to study the correlation between hydrological drought, natural hydroclimate variability, and human interventions.

Secondly, to evaluate the water scarcity phenomena [24], water consumption and water abstraction data have been introduced. The WSI, in fact, utilizes these data [25], which can also be extended to the concept of environmental water requirements [26,27], and indicates the amount of water exploited and used with respect to freshwater availability. In 2012, the Water Scarcity and Drought Expert Group of the European Commission introduced the Water Exploitation Index (WEI), which was later reviewed and upgraded in the form of the $\mathrm{WEI}^{+}[1]$, within a set of common indicators for water scarcity and drought. The WEI is a water scarcity indicator, which is calculated as the average demand for freshwater divided by the long-term average of freshwater resources. The proposed $\mathrm{WEI}^{+}$incorporates returns from water uses, therefore taking into account the net water abstraction.

It can be observed that during the last few years, many studies have been published regarding the SPI, SPEI, SRI, and WSI; however, studies providing applications of $\mathrm{WEI}^{+}$are extremely rare, specifically at local spatial resolutions and with seasonal or monthly time steps. In the European Environment State and Outlook 2015 report [28], the WEI was applied at the national scale in Mediterranean countries, showing that southern countries (e.g., Egypt, Israel, Syria, Libya, and Malta) are amongst the most water-stressed. Contreras and Hunink [29] analyzed the patterns of water use and supply at the basin scale in the Segura River Basin, where the $\mathrm{WEI}^{+}$was 0.86 on average, although it showed a strong spatial and temporal variability, with the highest value (1.52) found in the Northeastern Elementary Watershed Management Units. De Roo et al. [30] studied the average monthly $\mathrm{WEI}^{+}$in the Sava region, considering various land-use and climate change scenarios up until 2050. Karabulut et al. [31] applied the $\mathrm{WEI}^{+}$to the Danube river basin and provided maps of possible water scarcity in its sub-basins.

Despite the above, attempts to apply the $\mathrm{WEI}^{+}$have been less successful than expected. One of the main problems is seasonality, as annual averages are generally not able to capture scarcity events and a monthly scale would be better; as well as the inappropriateness of input data and the consequent uncertainty in the assessment of demands and water resources values, which can lead to incorrect indicator values [32,33]. In order to solve these problems, the present study proposes new instruments and a methodology for data availability at different spatial and temporal scales. Specifically, the adoption of a Web-GIS database to analyze the space-time dynamics of water demands and the use of flow duration curves (FDC) to evaluate water resources. FDC are widely regionalized [34-37], thus offering a great advantage for ungauged basins.

The next section describes the methodology, focusing on the definition of the $\mathrm{WEI}^{+}$and critical points, and it introduces a new approach to analyze water abstractions and evaluate the total available water. This is followed by the presentation of several results regarding the case study and validation considering three little basins in the Upper Tiber River Basin. The main conclusions of this work are summarized in the final sections.

\section{Materials and Methods}

\subsection{Water Exploitation Index $\left(\mathrm{WEI}^{+}\right)$}

The $\mathrm{WEI}^{+}$is a water scarcity indicator, which provides an evaluation of the stress on water resources as a consequence of human activity in terms of water abstractions. It is calculated as follows:

$$
\mathrm{WEI}^{+}=\frac{\text { abstraction }- \text { returns }}{\text { renewable water resources - environmental flow }}
$$


where abstractions must be evaluated net of water returns, and therefore, it is necessary to know the water use in relation to its consumption, as well as the spatial location of possible water returns. Renewable water resources (RWR) take into consideration external inflow and internal flow in the basin, minus the environmental flow requirement.

The Water Scarcity and Drought Expert Group of European Commission [1] has suggested two ways to evaluate the RWR in areas with human alterations:

$$
\begin{gathered}
\mathrm{RWR}=\mathrm{Ex}_{\text {inf }}+\mathrm{P}-\mathrm{Et}_{\mathrm{a}}-\Delta \mathrm{S}_{\text {nat }} \\
\mathrm{WR}=\mathrm{Q}_{\text {nat }}=\mathrm{Q}_{\mathrm{obs}}+(\text { abstractions }- \text { returns }) \pm \Delta \mathrm{S}_{\text {art }}
\end{gathered}
$$

Equation (2) employs the natural hydrological balance equation, taking into account possible external natural inflows ( $E x_{\text {inf }}$ ), such as other river basin districts, in the case of the balance equation at the spatial resolution of a specific district. Other terms are as follows: $\mathrm{P}$ is precipitation, $\mathrm{Et}_{\mathrm{a}}$ is the actual evapotranspiration, and $\Delta \mathrm{S}_{\text {nat }}$ is the change in natural storage.

Equation (3) identifies the RWR with the volume of natural runoff $\left(Q_{n a t}\right)$, which can be estimated by the observed runoff $\left(\mathrm{Q}_{\mathrm{obs}}\right)$ plus upstream water abstractions minus returns, adding the change in upstream artificial storage ( $\pm \Delta S_{\text {art }}$ ), such as artificial reservoirs.

It is reasonable to argue that these two ways of estimating the RWR are not independent from one another; in fact, to calibrate and validate Equation (2), it is necessary to know the volume of natural runoff from Equation (3).

The quality of the index depends on the quality of the input data, and so, the deep knowledge of water abstractions is a particular focal point of $\mathrm{WEI}^{+}$calculation.

\subsection{Water Abstractions Evaluation}

Data on water abstractions are often very sparse and inconsistent. Ziolkowska and Ziolkowski [38,39] showed that in many European countries, there is still a deep lack of information and data; specifically, agricultural water use data in southern Europe is very problematic due to a lack of updated information, making any estimate of this critical issue very difficult [40].

Therefore, in this study, a new database is used that contains extensive data on water use at the basin level, which is vital to facilitate and design sustainable water evaluation and management policies and practices. The new database is supported by a GIS system for the spatial analysis of data, as well as a web application. The web service has several main advantages: it is available all the time, it is accessible from anywhere, and it creates a real-time multi-user collaboration platform [41].

WEB-GIS of water abstractions [42] serves the main instrument to implement the evaluation of the term "abstractions minus returns" in Equations (1) and (3). In fact, for existing water abstractions, an analysis procedure has been developed which, starting from the point selected directly by clicking on the map, finds the upstream basin and, by means of overlay procedures, identifies the water uses in the basin. In order to obtain a more detailed assessment, a search tool has also been developed, such that water abstractions can be retrieved on the basis of the type of use, the amount of water allowed, the administrative status, and the possible return point. All these data can be exported as a .csv file.

The result of this methodology is the possibility of evaluating each abstraction and return where the $\mathrm{WEI}^{+}$must be calculated. In the present study, the total abstraction data in the basin were used $\left(\mathrm{AB}_{\mathrm{tot}}\right)$, which were provided by the WEB-GIS, through filtering the maximum abstractions in the basin and returning the total values $\left(Q_{\text {tot } \max }\right)$ for each type of water use (i). These values are multiplied by an average coefficient of each abstraction curve in the examined period $(\alpha)$ and by a coefficient that 
takes into account the water consumption (the dissipative efficiency $\mathrm{E}$ : $\mathrm{E}=1$ for irrigation use, $\mathrm{E}=0.5$ for domestic use, and $0<\mathrm{E}<1$ for others types of use).

$$
\mathrm{AB}_{\text {tot }}=\sum_{\mathrm{i}=1}^{\mathrm{n}}\left(\mathrm{Q}_{\text {tot } \max } \cdot \alpha_{\text {avg }} \cdot \mathrm{E}\right)_{\mathrm{i}}
$$

The support of the Web platform using GIS technology allows for easy updating of this very important data in $\mathrm{WEI}^{+}$evaluation, which often involves co-operation among different local institutions in the river basin district and, consequently, the necessity of sharing information and knowledge easily.

\subsection{Flow Duration Curves and Renewable Water Resources Evaluation}

To evaluate the $\mathrm{WEI}^{+}$, knowledge of renewable water resources is fundamental. In this study, an alternative to Equations (2) and (3) is suggested for evaluating the RWR, based on flow duration curve estimation.

The flow duration curve has been widely used in many sectors, both to assess the availability of water resources and for low flow and water quality analysis. For these reasons, regionalization techniques for the FDC have been produced, as mentioned above, which allow for the use of FDC in ungauged basins. A technique for regionalization of the natural FDC based on the log-normal distribution was used in the present work, which was applied to a suitable time-series of naturalized flows of gauged stations in the Upper Tiber River Basin [42]. To evaluate the suitability of the log-normal model, a measure of the standardized mean square error, commonly referred to as the Nash-Sutcliffe efficiency (NSE) was used [43]. As the NSE is heavily influenced by the highest flows, it was computed based on the natural logarithms of the flows and, thus, it is referred to as LNSE [34]. The model is considered to show good fit when LNSE $>0.93$.

For the purposes of evaluations of the $\mathrm{WEI}^{+}$, the natural FDC was used to calculate the RWR, assuming the value to be equal to the area underlying the curve and choosing the use of the duration of a certain period of days on the time axis to define the month or season.

\section{Case Study and Results}

The process described in the previous paragraphs was applied to some sub-basins in the Tiber River Basin, located in central Italy (Figure 1A). The Tiber is the third-longest river in Italy, and its basin has an area of $17,462 \mathrm{~km}^{2}$. Water resources management in this basin is very complex; the number of total water abstractions authorizations in the Tiber River Basin has been estimated at 10,500, about $60 \%$ of which is for irrigation [44]. This percentage increases up to $80 \%$ in the Upper Tiber River Basin. In this scenario, calculation of the $\mathrm{WEI}^{+}$index in the various parts of the basin could be very useful to identify the imbalances in water resources management and water abstractions. However, a lack of reliable data in many sub-basins makes it very difficult to apply the European Commission (EC) method described in Section 2.1. For this reason, our proposed approach to calculate the $\mathrm{WEI}^{+}$was tested in three sub-basins in the Upper Tiber River Basin (Figure 1B), where the availability of data allowed us to also apply the EC method.

In particular, to carry out a comparison between the methodology suggested by the European Commission and the proposed one with the duration curves, the case study basins described in Table 1 were chosen. The climate of the case study basins is characterized as a Mediterranean climate, with precipitation occurring mostly from autumn to spring seasons. Based on data in the observed period, the mean annual rainfall was in the range of $860-940 \mathrm{~mm}$. All these basins are gauged basins, where the average daily discharge is $0.677-0.910 \mathrm{~m}^{3} \mathrm{~s}^{-1}$ with a minimum value of $0.077-0.148 \mathrm{~m}^{3} \mathrm{~s}^{-1}$ during drought periods, and they are characterized by a low base flow (Base Flow Index (BFI) $\leq 50[45,46]$ ), according to the geological characteristics of the Upper Tiber River Basin, where low-permeability formations (flysch sandstone clay, clay and sandstone, and limestone clay) predominate [47]. These characteristics make water resource management in these basins quite difficult, especially during the dry season, when an increase of 
irrigation water consumption occurs [48] and the balance between environmental and socioeconomic aspects becomes very difficult.

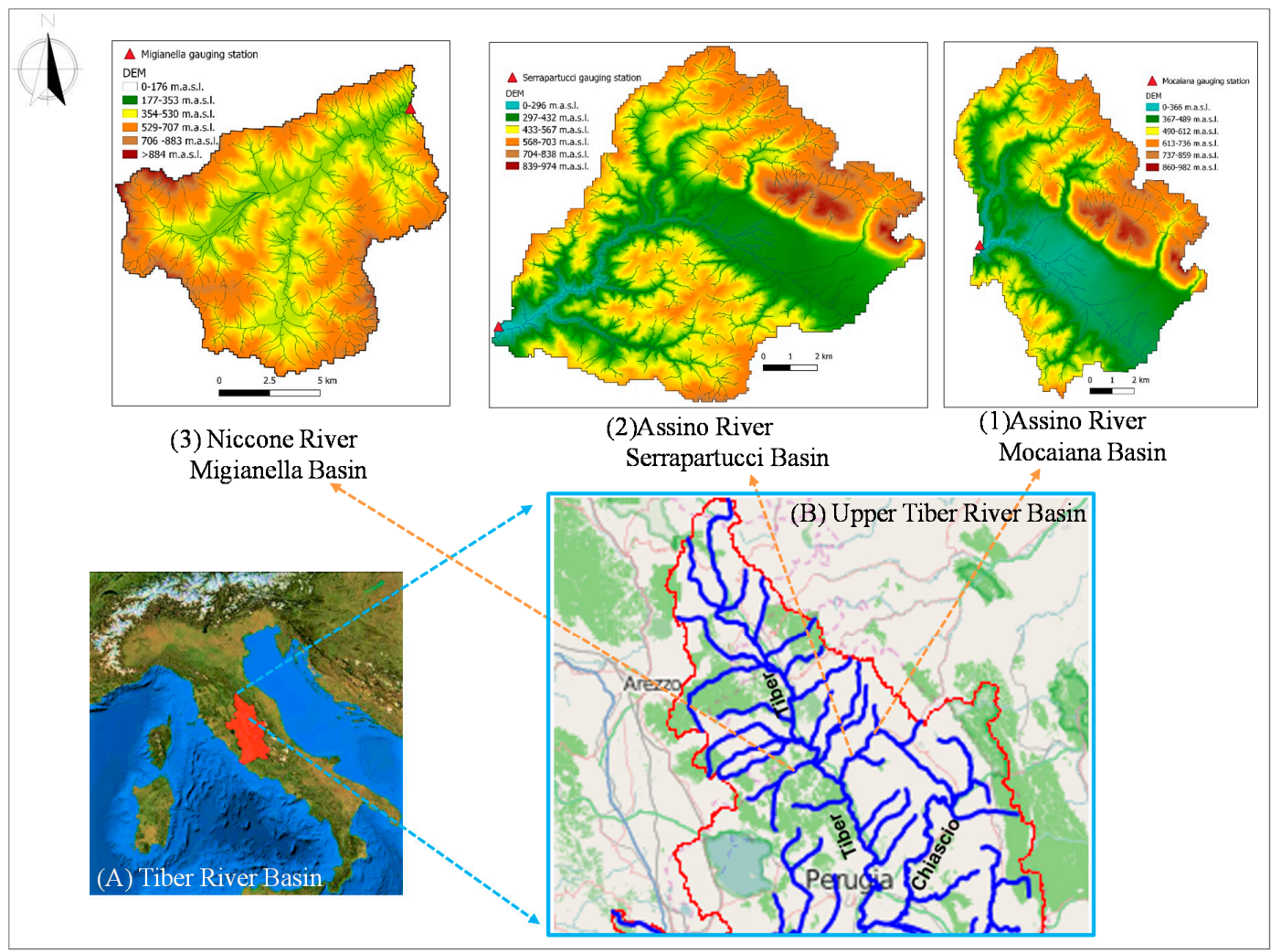

Figure 1. Map of the Tiber River Basin (A) and Upper Tiber River Basin (B) with the location of case study basins.

Table 1. Key characteristics of case study basins: observation periods, catchment area, Base Flow Index, and water abstractions.

\begin{tabular}{ccccccccc}
\hline Basin & \multicolumn{2}{c}{ Hydrometric Station } & \multicolumn{2}{c}{ Observed Period } & Area & BFI & \multicolumn{2}{c}{ Max Abstractions } \\
\hline & Station Name & River & From-To & $\begin{array}{c}\text { Size } \\
\text { (Years) }\end{array}$ & $\left.\mathbf{( k m}^{\mathbf{2}}\right)$ & $\mathbf{( \% )}$ & $\begin{array}{c}\text { Irri. } \\
\mathbf{( L / S )}\end{array}$ & $\begin{array}{c}\text { Domestic } \\
\text { (L/S) }\end{array}$ \\
\hline Tiber & Mocaiana & Assino & $1992-2005$ & 14 & 102.0 & 48 & 79 & 82.18 \\
Tiber & Serrapartucci & Assino & $1992-2005$ & 14 & 165.7 & 49 & 102 & 85.09 \\
Tiber & Migianella & Niccone & $1996-2005$ & 10 & 135.7 & 42 & 130 & 0.10 \\
\hline
\end{tabular}

The main quality of the basins in our case study is that the water abstractions framework is the most known possible, which is very important for testing the $\mathrm{WEI}^{+}$index. However, even in this case, it was not possible to obtain reliable information on irrigation abstractions, specifically regarding the seasonal and monthly distribution of water abstractions.

For this reason, in both methods of calculation, a standard abstraction curve for irrigation was used, which applied to the maximum water flow allowed. The irrigation water abstraction was calculated as $\mathrm{Q}_{\text {irr }}=\alpha \cdot \mathrm{Q}_{\max }$, where daily values of the parameter $\alpha$ are shown in Figure 2 (red line). In the case of FDC (green line), the maximum abstraction was located at the end of the curve, in accordance with the hypothesis that the maximum abstraction occurs during the peak of a drought period, where the duration, or the percentage of time when a specific flow is equal or exceeded, is more than 350 days. 


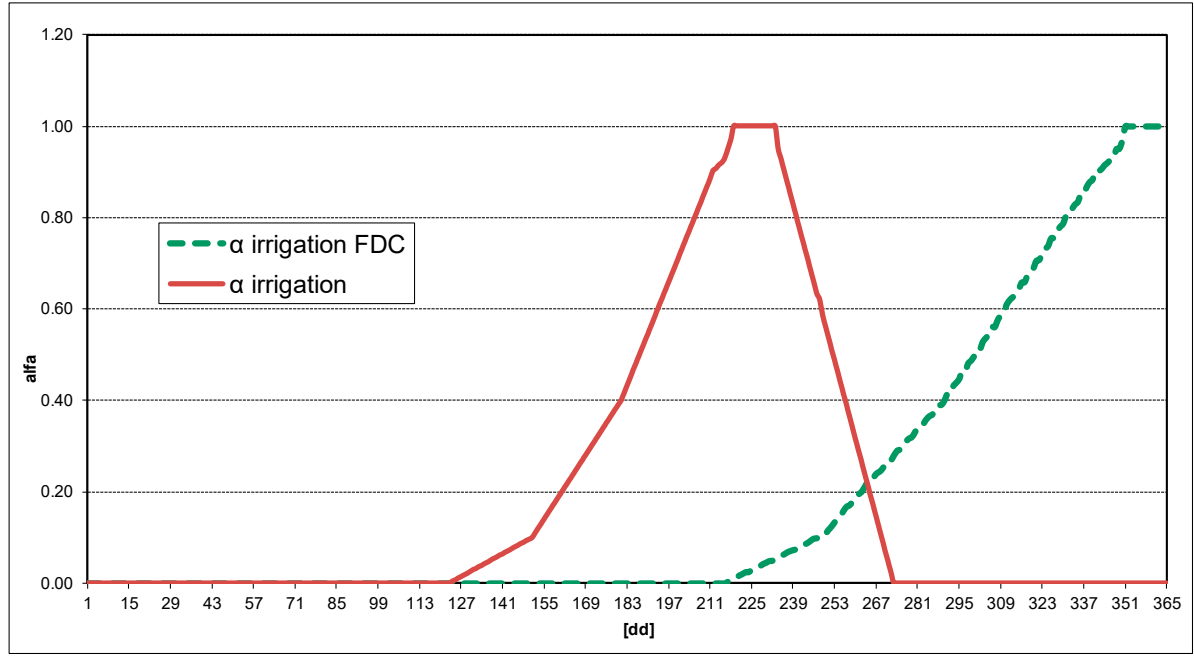

Figure 2. Alpha $(\alpha)$ standard coefficient for irrigation water abstraction.

Figure 3 shows the overlap of the FDC with the FDC of the irrigation abstractions ( FDC $\left._{a b s}\right)$, according to the green line of Figure 2, with the constraint of the environmental flow requirement (EFR). When the $\mathrm{FDC}_{\mathrm{abs}}$ is above FDC, the total irrigation abstractions are no longer possible. The result is the FDC of the real irrigation abstractions ( FDC $_{\text {real-abs }}$ ). The hypotheses of Figure 2 (green line) and of a constant EFR are certainly burdensome, in terms of water abstractions; however, they are suitable to describe the most critical situations in terms of water scarcity.

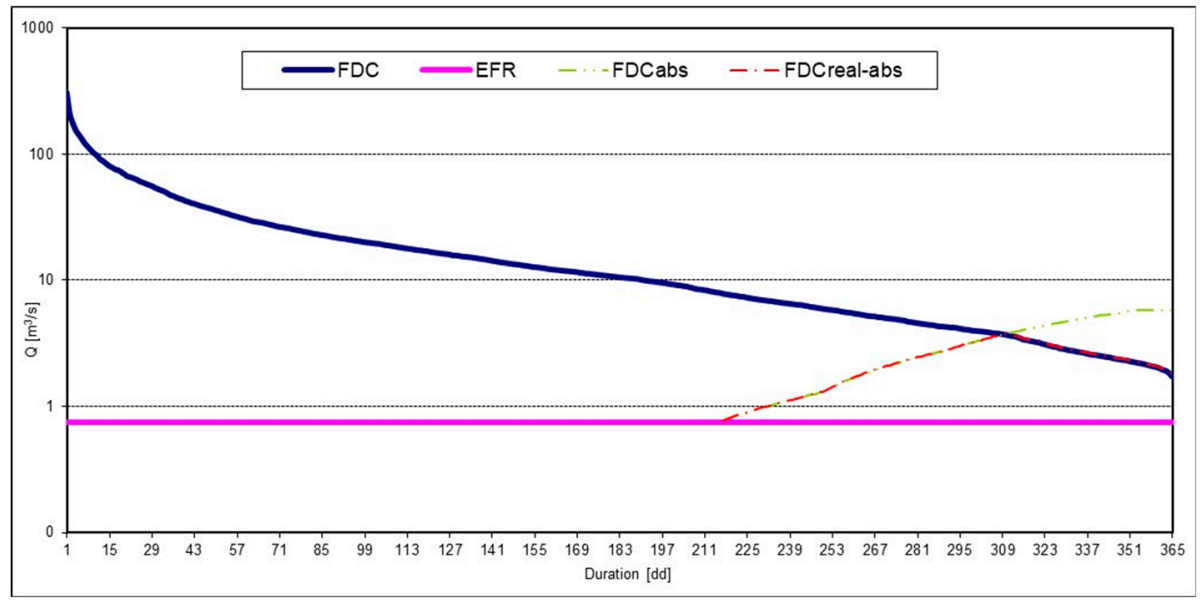

Figure 3. Flow Duration Curve (FDC), environmental flow requirement (EFR), FDC of irrigation abstractions $\left(\mathrm{FDC}_{\mathrm{abs}}\right)$ and $\mathrm{FDC}$ of real irrigation abstractions $\left(\mathrm{FDC}_{\text {real-abs }}\right)$.

Once the methods for managing each irrigation water abstraction were defined, the technique of regionalization of natural FDC, as described in Section 2.3, was tested in the three case study basins.

The observed FDC, natural FDC, and estimated natural FDC were calculated for each case study basin; in particular, the observed FDC was obtained from time-series data of hydrometric stations in terms of the average FDC (as per Vogel and Fennessey [49]), the natural FDC was obtained from natural daily flow time-series reconstruction by means of observed data and abstractions data [42] and, finally, the estimated natural FDC was the result of the proposed regionalization technique. Figures 4-6 show a comparison between these three types of FDC, where the observed FDC was always clearly majorly influenced by water abstractions (particularly at the end of the FDC), as the irrigation water abstractions had a heavy influence on the monitored flow and depressed the curve irregularly. The Migianella basin was the most stressed basin, due to irrigation water abstractions 
(Table 1 and Figure 6). This situation had a negative influence on the reconstruction of the natural flow and, consequently, on the comparison between the natural FDC and the estimated natural FDC. In fact, Figures 4 and 5 show a good fit between the estimated natural FDC and natural FDC, with LNSE $=0.972$ and LNSE $=0.964$ respectively; while at Migianella station (Figure 6), there was a significant overestimation and LNSE $=0.902$ (just below the threshold of good fit).

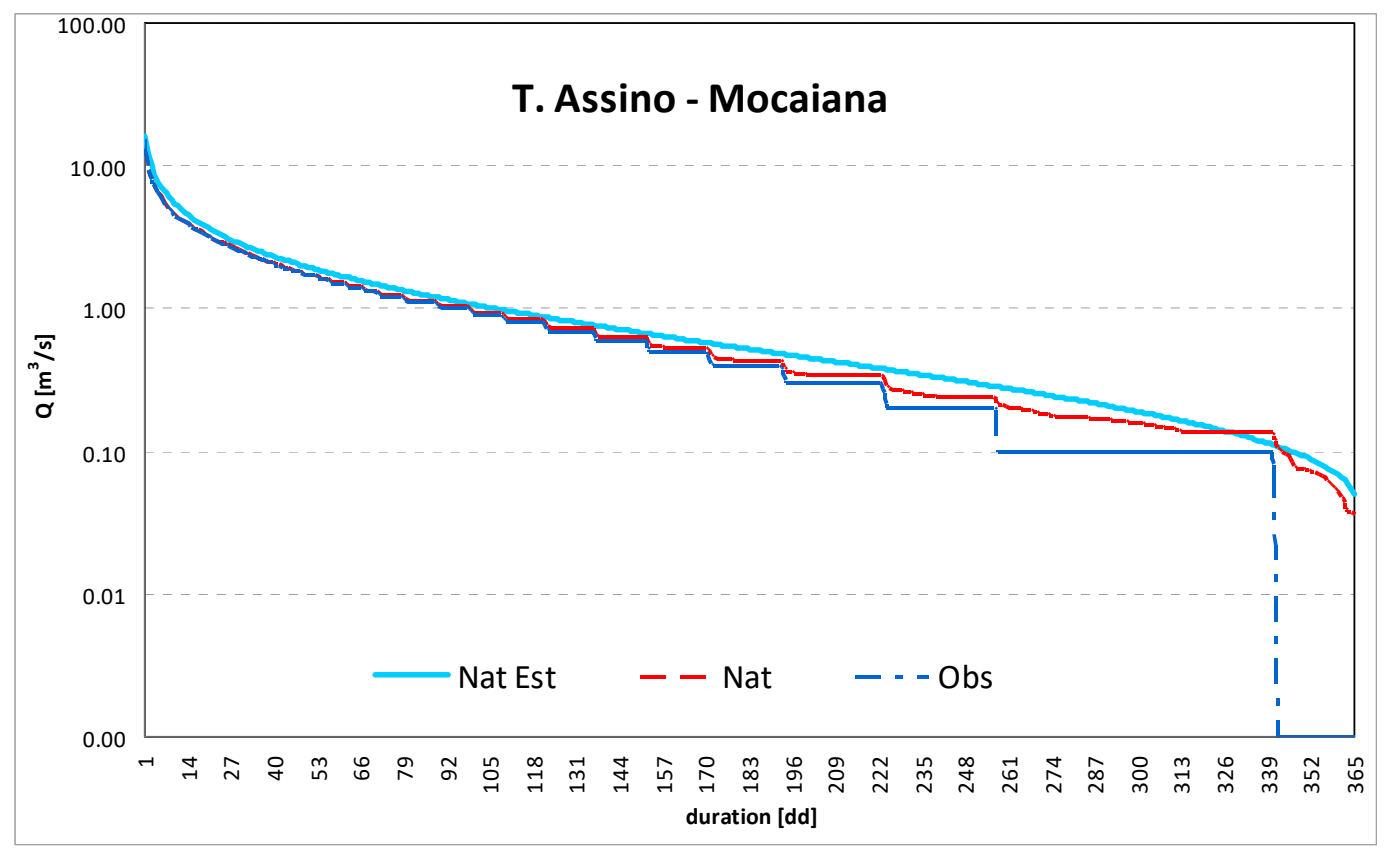

Figure 4. Flow duration curves (FDCs) in the Mocaiana basin. Estimated natural FDC (Nat Est), natural FDC (Nat), and observed FDC (Obs).

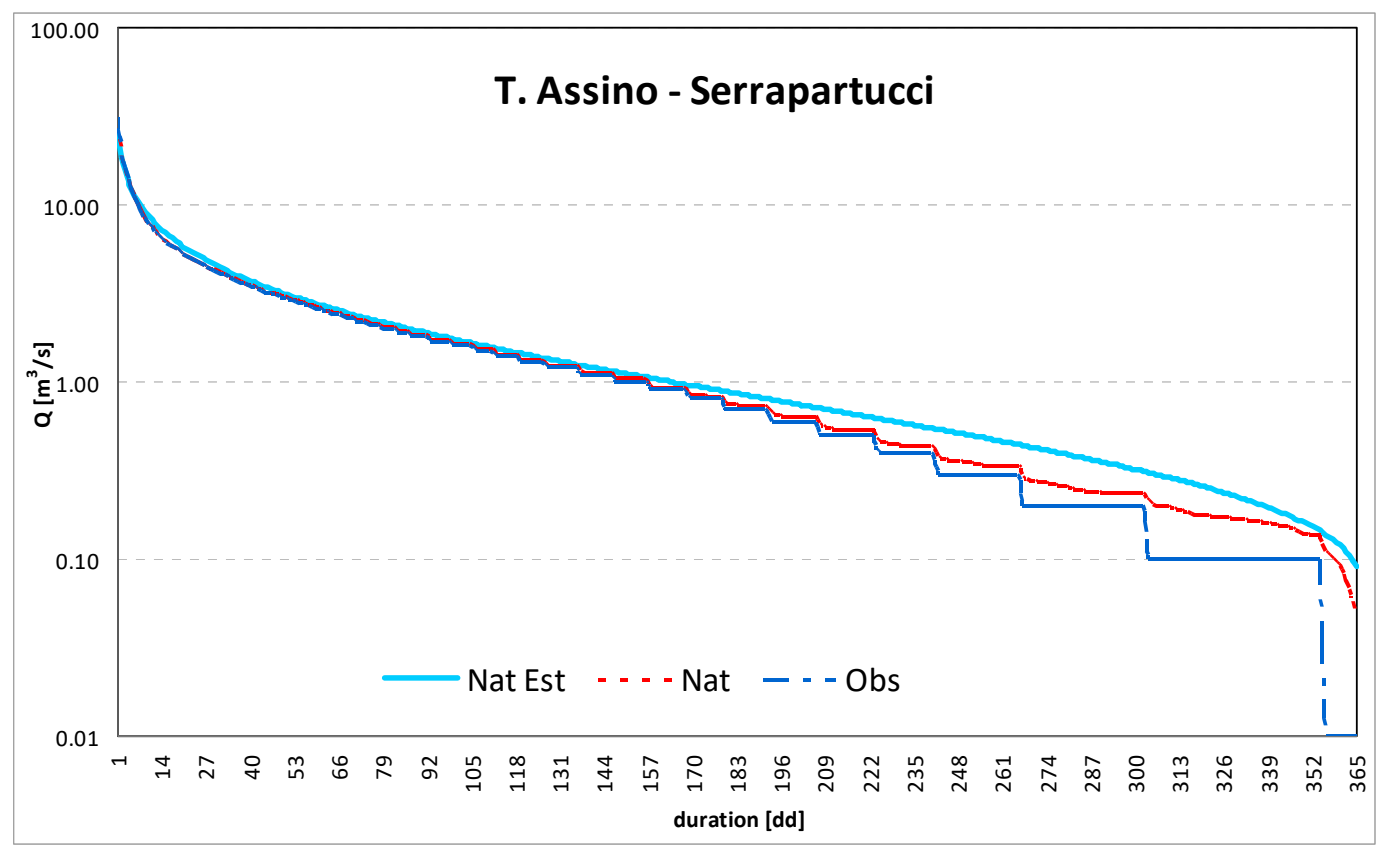

Figure 5. Average FDCs in the Serrapartucci basin. Estimated natural FDC (Nat Est), natural FDC (Nat), and observed FDC (Obs). 


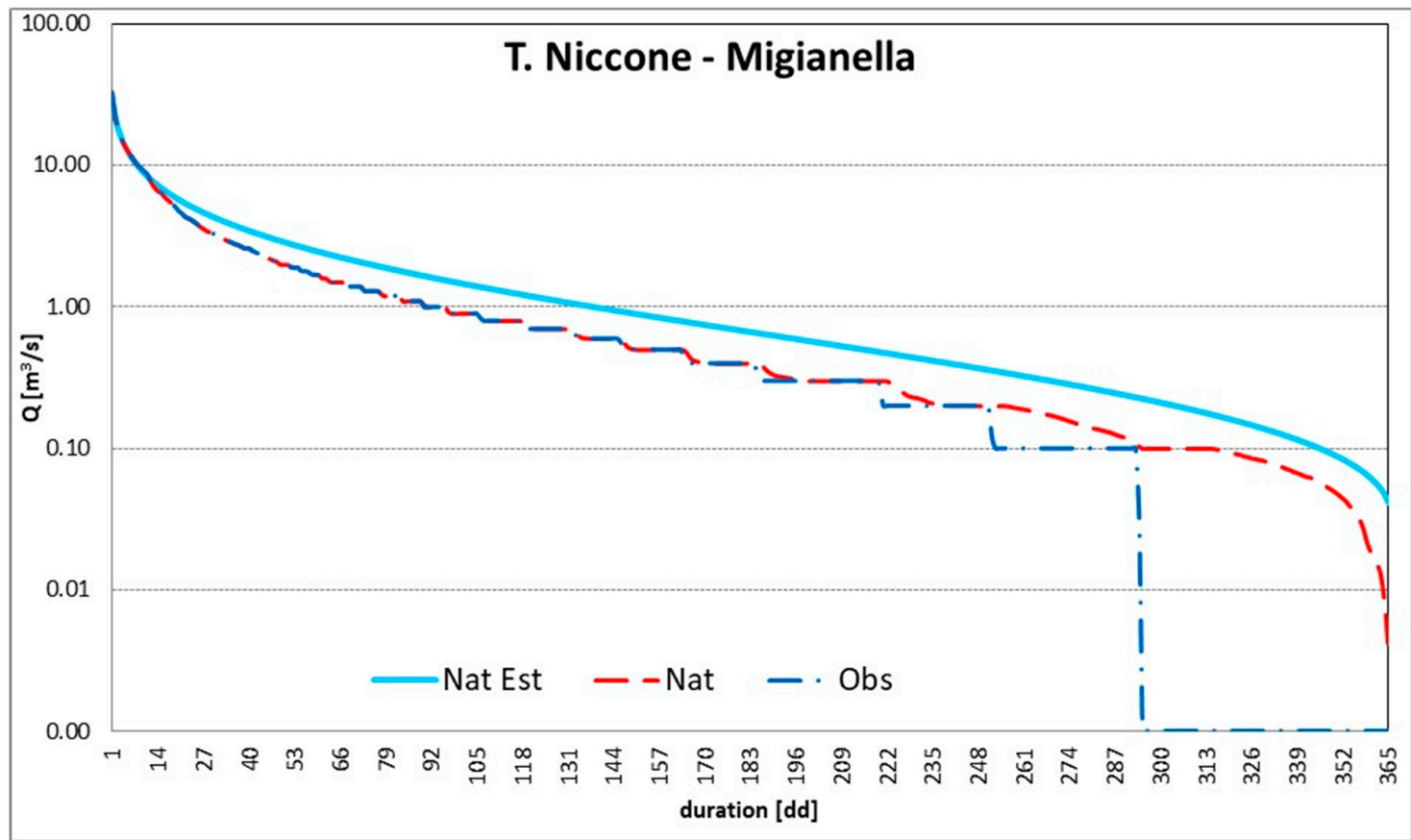

Figure 6. Average FDCs in the Migianella basin. Estimated natural FDC (Nat Est), natural FDC (Nat), and observed FDC (Obs).

In the subsequent calculation of the $\mathrm{WEI}^{+}$index, little focus was put on the annual value but, rather, on the seasonal value and the peak month. Specifically, the seasonal value for the irrigation period (June-September) was considered significant, while the month of August was used for the monthly value.

The $\mathrm{WEI}^{+}$, according to the EC method, was obtained using Equations (1) and (3) for each year in the irrigation period and for the month of August. The final value for comparison using the simplified methodology was the average of the annual values for each period.

The $\mathrm{WEI}^{+}$calculated with the simplified methodology adopted the basin's natural FDC for the calculation of the volume of the renewable water resources in the irrigation period and in the peak month, using the areas under the curve, for the duration of 234-355 days and 325-355 days, respectively, thus concentrating all the flows of these periods in the final part of the FDC. The extreme end of the FDC was not considered, in this case, as we believed that the low flow cannot be evaluated as a useful resource to be counted in an index that substantially measures the water stress in a river due to water withdrawals. For the calculation of abstractions minus water returns, the total abstraction data in the basin were used $\left(\mathrm{AB}_{\mathrm{tot}}\right)$, according to Equation (4).

The results are shown in Table 2, where the $\mathrm{WEI}^{+}$values for each basin are compared. In particular, the $\mathrm{WEI}^{+}$irr is the average of the $\mathrm{WEI}^{+}$time-series in the irrigation period and $\mathrm{WEI}^{+}$max is the average of the $\mathrm{WEI}^{+}$time-series in August, as calculated according to the $\mathrm{EC}$ method; meanwhile, $\mathrm{WEI}^{+} \mathrm{FDCirr}$ is the $\mathrm{WEI}^{+}$in the irrigation period and $\mathrm{WEI}^{+}{ }_{\mathrm{FDCmax}}$ is the $\mathrm{WEI}^{+}$in August, as calculated using the FDC approach.

Table 2. Water Exploitation Index $\left(\mathrm{WEI}^{+}\right)$in the studied catchments.

\begin{tabular}{|c|c|c|c|c|c|c|}
\hline \multicolumn{3}{|c|}{ Hydrometric Station } & \multirow{2}{*}{$\mathrm{WEI}^{+}$FDCirr } & \multirow{2}{*}{$\mathrm{WEI}^{+}{ }_{\text {irr }}$} & \multirow{2}{*}{$\mathrm{WEI}^{+}$FDCmax } & \multirow{2}{*}{$\mathrm{WEI}^{+}$max } \\
\hline Id. & Station Same & River & & & & \\
\hline 1 & Mocaiana & Assino & 0.39 & 0.27 & 1.02 & 0.53 \\
\hline 2 & Serrapartucci & Assino & 0.20 & 0.13 & 0.71 & 0.41 \\
\hline 3 & Migianella & Niccone & 0.29 & 0.25 & 1.07 & 0.71 \\
\hline
\end{tabular}


These values clearly show how the simplified methodology always overestimated the index calculated with the EC method, which was a consequence that was mainly due to the hypothesis of concentrating the volume of the irrigation abstraction in the final part of the FDC. In fact, this is more evident in the $\mathrm{WEI}^{+}$max value. Nevertheless, these differences are less apparent when examining the annual variations of the $\mathrm{WEI}^{+}$calculated according to the EC method (Figure 7).

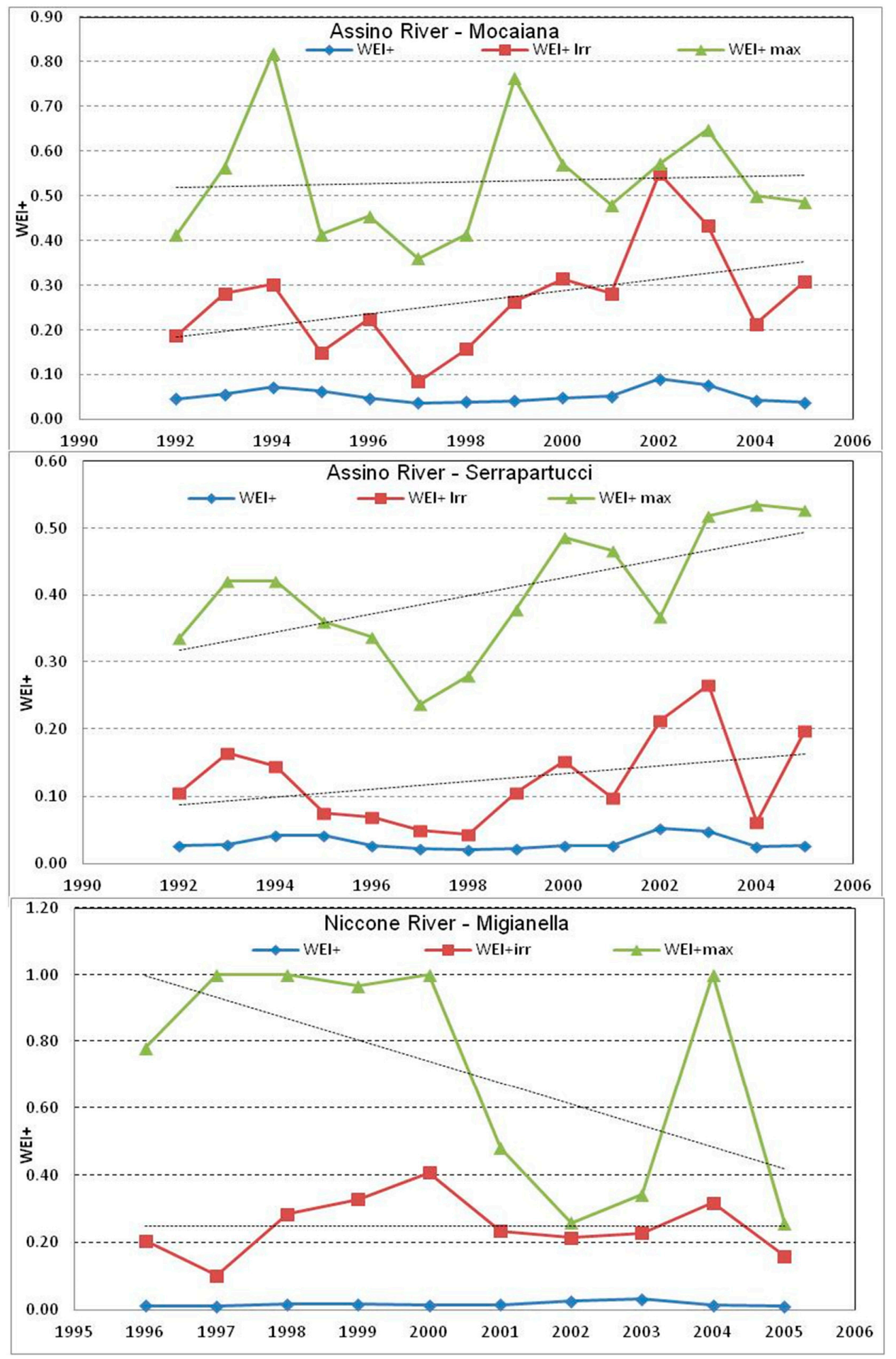

Figure 7. Variability and trend of annual $\mathrm{WEI}^{+}$calculated with the European Commission (EC) method. 
The annual variability of $\mathrm{WEI}^{+}{ }_{\text {max }}$, as well as $\mathrm{WEI}^{+}{ }_{\text {irr }}$, was due to the variability of the annual climate characteristics during the peak month and the irrigation period, which influenced the annual renewable water resources in Equation (1). The Mocaiana and Serrapartucci hydrometric station were located in the same Assino basin and showed similar variability and trends. Migianella station is located in a different basin, on the other side of the Upper Tiber River Basin, where irrigation water use variability is more accentuated and, consequently, showed a higher $\mathrm{WEI}^{+}$max variability. However, in all the studied basins, due either to maximum values or to trend, a reduction in the difference between the EC method and simplified methodology values was observed.

These latter considerations underline how the simplified method is suitable for highlighting seasonal or monthly situations of maximum stress in terms of water abstractions in the basin. Nonetheless, another important aspect is that the simplified methodology proposed in this work allows for regionalization of the calculation of the $\mathrm{WEI}^{+}$at a very detailed sub-basin level. The use of WEB-GIS for water abstractions and regionalization techniques for natural FDC allows for the rapid calculation of the $\mathrm{WEI}^{+}$in many sub-basins. In Figure 8, the $\mathrm{WEI}^{+}$values for the Upper Tiber River sub-basins are represented, while Figure 9 displays the map of $\mathrm{WEI}^{+}$irr in all of the Upper Tiber River basin. It is possible to observe that there are many sub-basins with very high $\mathrm{WEI}^{+}{ }_{\text {irr }}$ values, especially in the downstream basins. If we consider the average value in the portion of the Upper Tiber River basin to which the regionalization was applied $\left(2187 \mathrm{~km}^{2}\right)$, we obtain $\mathrm{WEI}^{+}{ }_{\text {irr }}=74.65 \%$. However, the most important result that Figure 8 shows is the value of $\mathrm{WEI}^{+}$max (peak month), with the majority of the sub-basins having values over $1\left(\mathrm{WEI}^{+}>100 \%\right)$. According to the definition of the $\mathrm{WEI}^{+}$, this result can be seen as indicating a very unsustainable scenario, even for a short period of time.

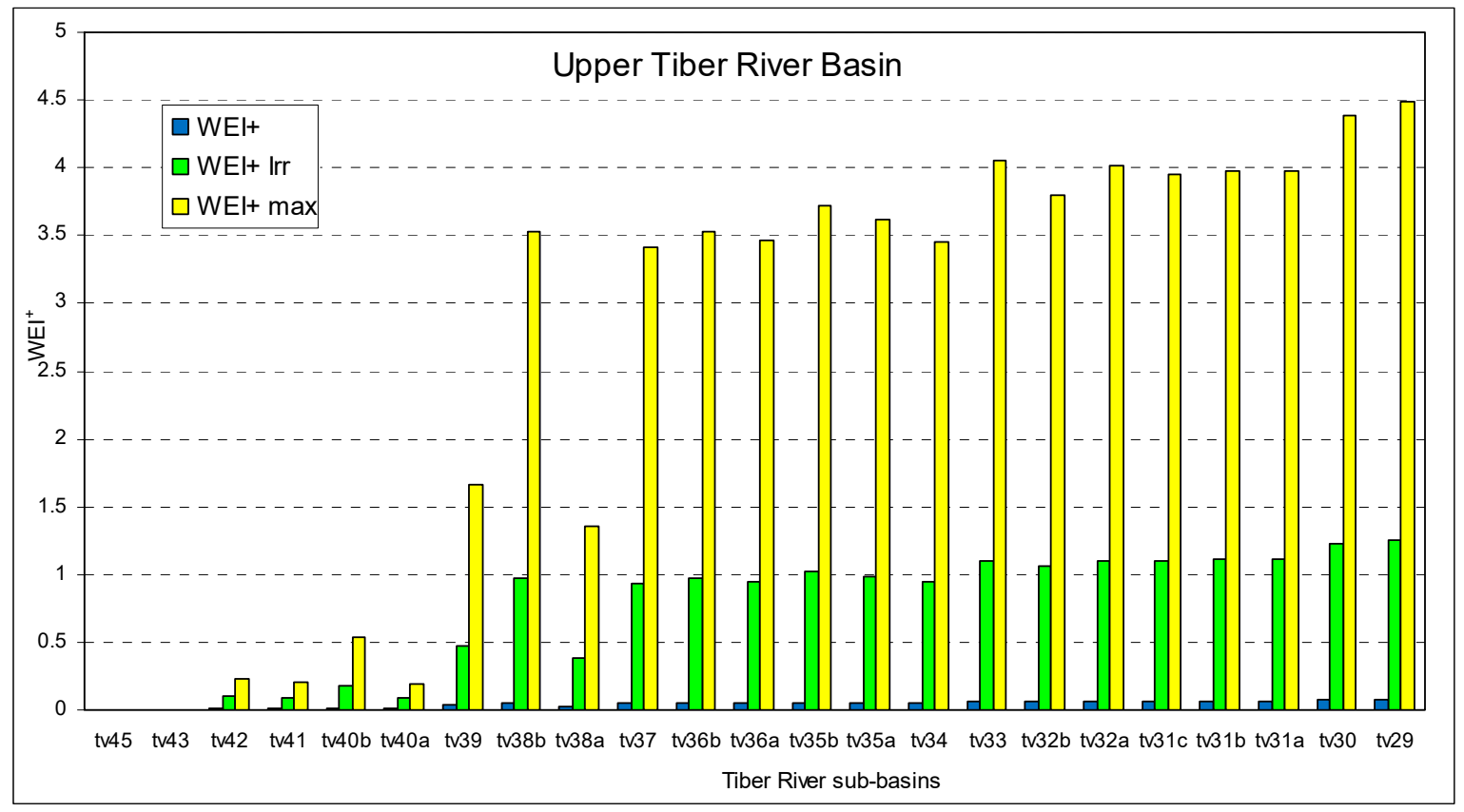

Figure 8. $\mathrm{WEI}^{+}$in the Upper Tiber River sub-basins. 


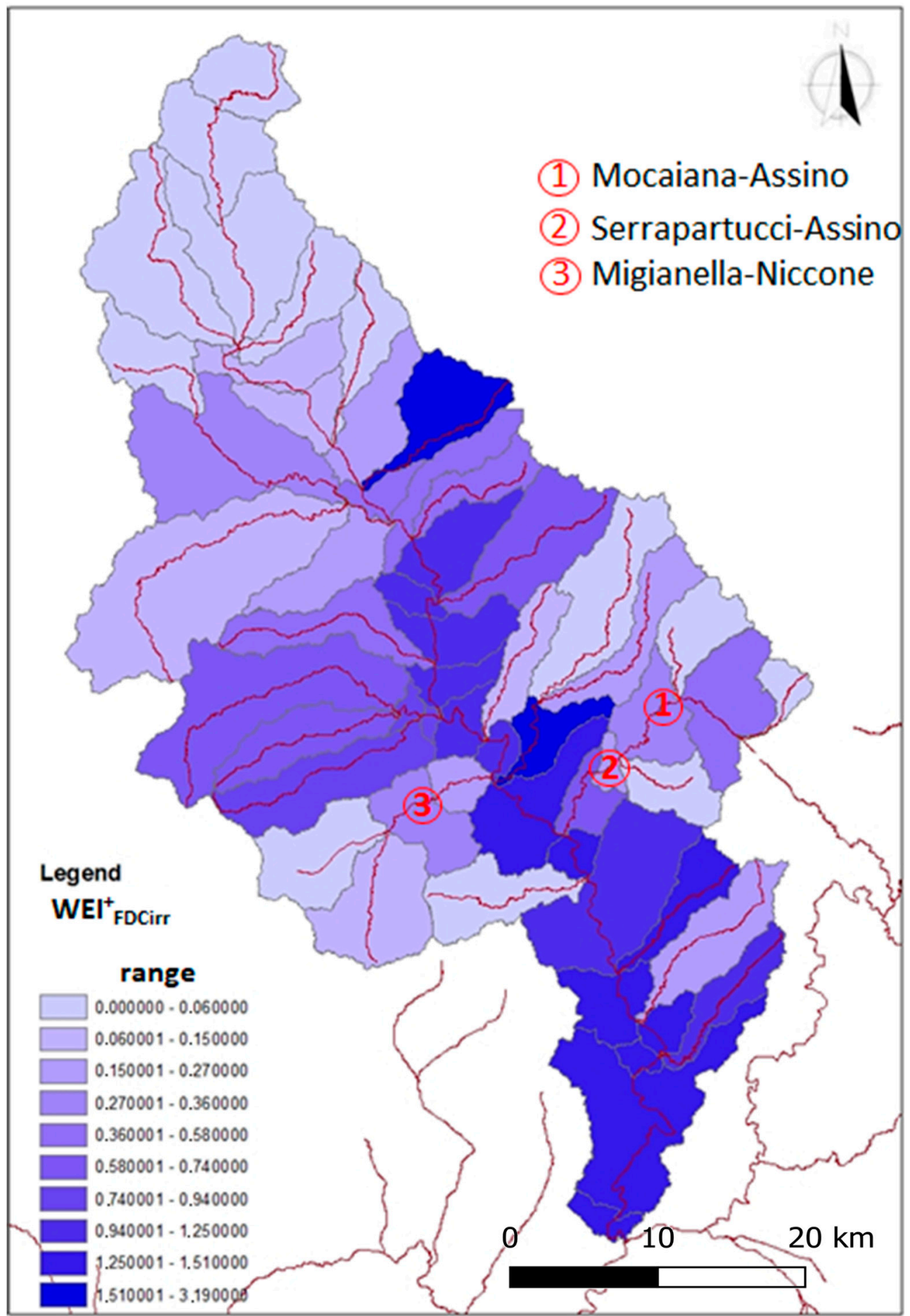

Figure 9. Map of $\mathrm{WEI}^{+}{ }_{\text {irr }}$ in the Upper Tiber River Basin.

These results demonstrate water management stress in the Upper Tiber River basin, with possible relevant impacts in the socio-economic field; for example, León et al. [50] estimated the total costs of agricultural droughts as a percentage of Gross Domestic Product losses in Italy. These losses ranged from $0.03 \%$ under mild drought stress to $0.05 \%$ and $0.10 \%$ under moderate and extreme drought levels, respectively. These damages are concentrated in but extend beyond the agricultural sector, with substantial identified impacts on food industry manufacturing and wholesale and trade services. 


\section{Discussion}

Once we tested the new approach to calculate the $\mathrm{WEI}^{+}$in the three case study basins, then applied it to all sub-basins of the Upper Tiber River Basin, and these results are compared with data published by the European Environment Agency (EEA) for the river basin districts. These data are the only ones that can be used in the Tiber River Basin to compare the values obtained in this study, allowing us to evaluate the improvements that the proposed methodology could offer in water scarcity management.

The website of the European Environment Agency [51,52] (first version before 2018 and updated version in November 2019) provides a large overview of $\mathrm{WEI}^{+}$for river basin districts, calculated by means of the EC method. An interactive map shows the $\mathrm{WEI}^{+}$as the quarterly average for the years 2002-2014 in the first version and 1990-2015 in the updated version.

The Upper Tiber River Basin is located in the Middle Appenines district, and the $\mathrm{WEI}^{+}$data were initially verified in the summer of 2003, which was a very dry period. The $\mathrm{WEI}^{+}$in this district was $15.94 \%$ in the first version (Figure 10) and 32.37\% in the second version (Figure 11). A second check was carried out in summer 2015, the last data available, with the value increasing up to $40.93 \%$ (Figure 12). This considerable increase was not due to a time factor but rather due to the availability of increasingly updated data; in particular, with regard to water abstractions. This confirms a deep lack of information and data in the first and second elaborations and consequently highlights the importance of developing and improving water abstraction management tools throughout the district, as described in Section 2.2 for the Tiber River Basin.

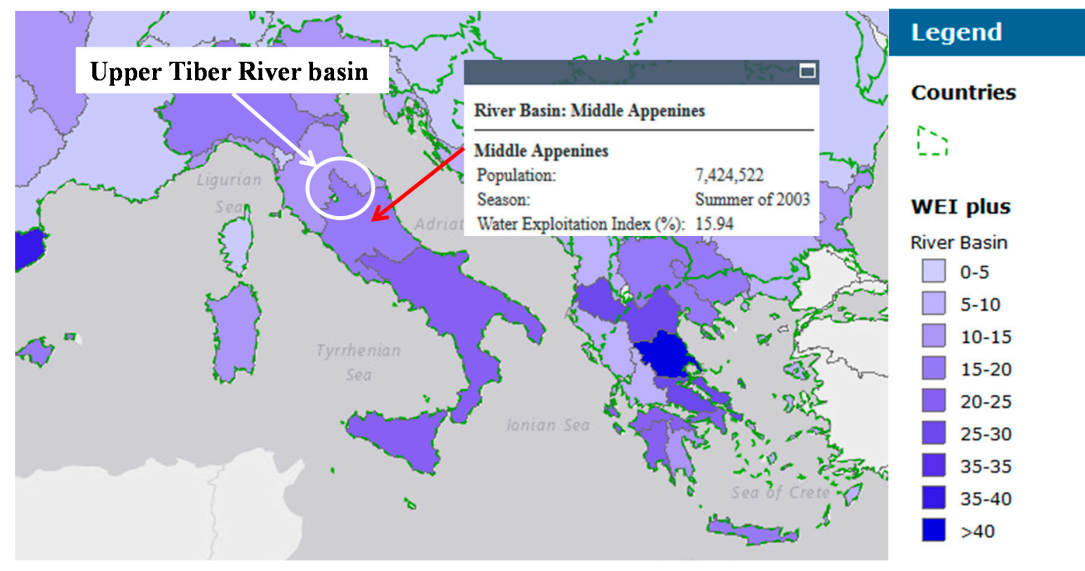

Figure 10. European Environment Agency, $\mathrm{WEI}^{+}$value in summer 2003 for the Middle Appenines District (first version, before October 2018).

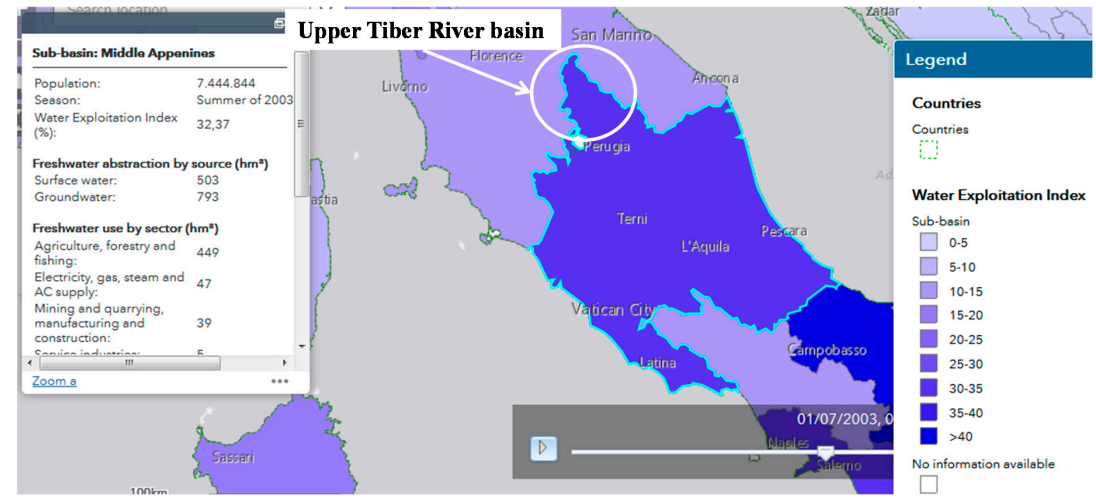

Figure 11. European Environment Agency, $\mathrm{WEI}^{+}$value in summer 2003 for the Middle Appenines District (Published 10 October 2018, last modified 28 November 2019). 


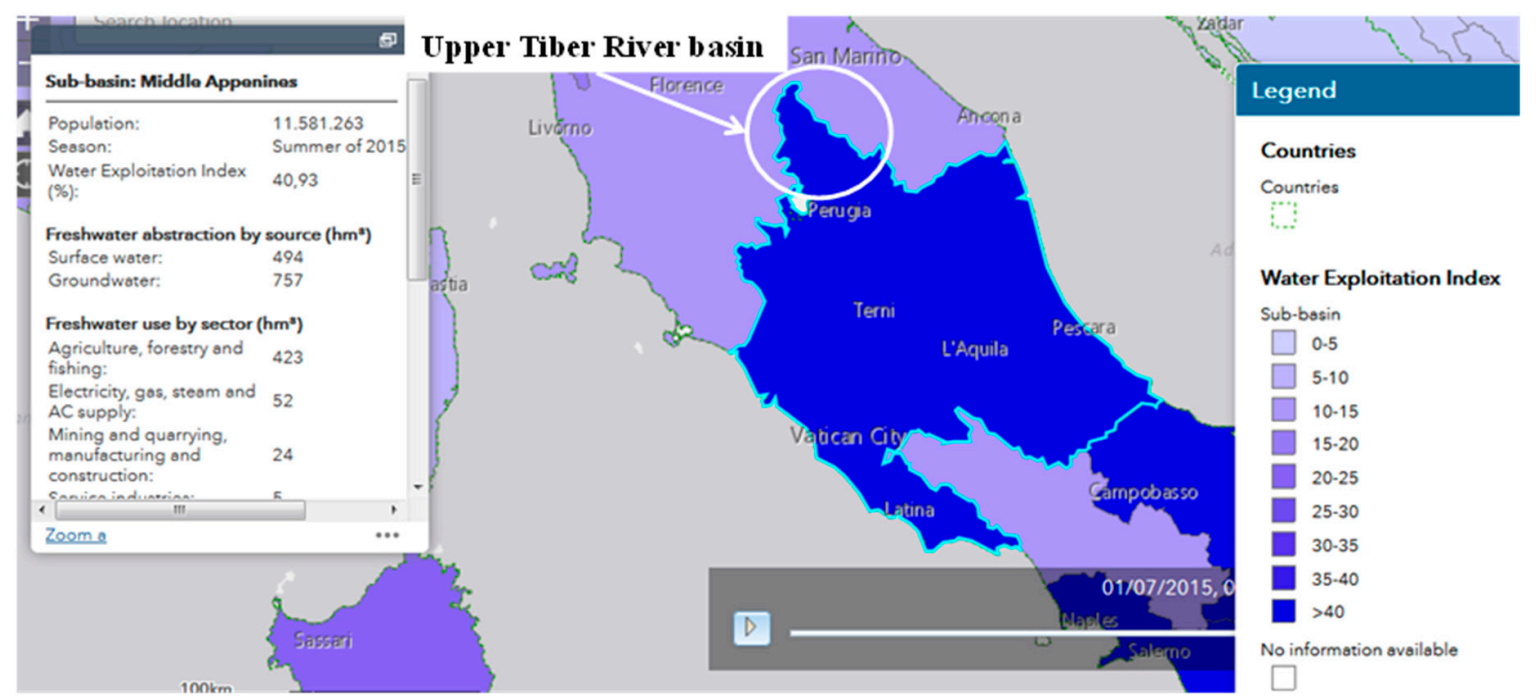

Figure 12. European Environment Agency, $\mathrm{WEI}^{+}$value in summer 2015 for the Middle Appenines District (published 10 October 2018, last modified 28 November 2019).

The EEA values refer to a very large area (approximately $42,506 \mathrm{~km}^{2}$ ) and, therefore, they can hardly provide useful indications for real operative rules on imbalances in water resources management and water abstractions. However, the $\mathrm{WEI}^{+}$values for the whole district were closer to those calculated in the studied basins with the simplified method rather than the EC method. The tendency of the simplified method to overestimate the $\mathrm{WEI}^{+}$values calculated with the European method could also be confirmed, but this difference cannot justify the peak values and may become less and less significant with the update of new data on the water abstractions used in the $\mathrm{WEI}^{+}$, as calculated with the EC method by the EEA.

A comparison with the data of the EEA revealed two significant aspects:

- $\quad$ The utility of the $\mathrm{WEI}^{+}$in drought management is linked to its detailed evaluation in basins and sub-basins;

- $\quad$ The $\mathrm{WEI}^{+}$values are more significant if evaluated in a specific period, such as the peak month.

The EEA data and the results of other studies cited in the introduction are lacking in these aspects. Conversely, the new approach to calculate $\mathrm{WEI}^{+}$achieved both of these goals, as demonstrated by the results of our case study. The first stage of a drought management plan is the identification of the vulnerable systems. The $\mathrm{WEI}^{+}$can be used to perform this task; however, both of the goals mentioned above must be achieved. For this reason, this work provides added worth to the literature in the field of drought management by $\mathrm{WEI}^{+}$evaluation.

\section{Conclusions}

In this research, the main objective was to evaluate a new approach to calculate the $\mathrm{WEI}^{+}$based on three pillars:

- The use of the natural FDC to calculate renewable water resources, assuming this volume to be equal to the area underlying the curve;

- The adoption of a WEB-GIS system for water abstractions, in order to calculate the value of "abstraction-returns" in all the basins and sub-basins;

- The use of regionalization techniques for the natural FDC to calculate the renewable water resources in ungauged basins and sub-basins.

The first results showed that the simplified approach could allow for simpler calculation of the $\mathrm{WEI}^{+}$index while maintaining the trends found in the $\mathrm{WEI}^{+}$values calculated using the traditional 
method. This result was verified both at the level of the case study basins and with synthetic data at the level of the Middle Appenines district.

The $\mathrm{WEI}^{+}$values calculated using this approach tended to overestimate the reference value; however, this result must be verified on a larger sample of basins. Moreover, this difference can also be compensated for through the adoption of higher critical threshold values of the index. The Water Scarcity and Drought Expert Group of the EC has indicated possible severe water stress when $\mathrm{WEI}^{+}>40 \%$. This value exposes the possibility of strong competition for water, but it does not necessarily lead to frequent water crises. In the simplified approach, a critical range in irrigation season and peak month can be assumed as $60<\mathrm{WEI}^{+}<80 \%$, in particular, in the downstream basins. However, currently, the main goal of this work was not to define a new critical threshold, but rather to build a methodology to evaluate the index in an overall manner and to contribute to a proactive approach for facing droughts. In fact, this calculation method can further allow for the rapid mapping of existing gaps in water abstractions and facilitate the planning of local interventions for the progressive mitigation of more critical events.

Future perspectives of this study will focus on the extension of the case studies in order to better validate the new approach. For this reason, knowledge of this method in the technical-scientific field would facilitate the experimentation of this approach in other basins, with different areas and more detailed water abstractions data. These outcomes would represent contributions toward the improvement of drought management policies.

Author Contributions: Conceptualization, formal analysis, funding acquisition, and supervision, S.C.; data curation, methodology, F.P.; data curation, software, A.P.; writing-review and editing, S.C. and F.P. All authors have read and agreed to the published version of the manuscript.

Funding: This research was funded by University of Perugia, basic research 2018 "Residual risk and its mitigation: reservoir management analysis".

Acknowledgments: The authors would like to thank the Regione Umbria for providing data for daily flow and water abstractions.

Conflicts of Interest: The authors declare no conflict of interest. The funders had no role in the design of the study; in the collection, analyses, or interpretation of data; in the writing of the manuscript, or in the decision to publish the results.

\section{References}

1. Faergemann, H. Update on Water Scarcity and Droughts indicator development. In EC Expert Group on Water Scarcity \& Droughts; European Environment Agency: Brussels, Belgium, 2012; pp. 1-23.

2. Wable, P.S.; Jha, M.K.; Shekhar, A. Comparison of Drought Indices in a Semi-Arid River Basin of India. Water Resour. Manag. 2019, 33, 75-102. [CrossRef]

3. Tsakiris, G. Drought Risk Assessment and Management. Water Resour. Manag. 2017, 31,3083-3095. [CrossRef]

4. McKee, T.B.; Doesken, N.J.; Kleist, J. The Relationship of Drought Frequency and Duration to Time Scales. In Proceedings of the 8th Conference on Applied Climatology; American Meteorological Society: Anaheim, CA, USA; Boston, MA, USA, 1993; pp. 179-184.

5. Saada, N.; Romman, A.A. Multi-site Modeling and Simulation of the Standardized Precipitation Index (SPI) in Jordan. J. Hydrol. Reg. Stud. 2017, 14, 83-91. [CrossRef]

6. Dabanl1, I.; Mishra, A.K.; Sen, Z. Long-term spatio-temporal drought variability in Turkey. J. Hydrol. 2017, 552, 779-792. [CrossRef]

7. Lu, J.; Jia, L.; Menenti, M.; Yan, Y.; Zheng, C.; Zhou, J. Performance of the Standardized Precipitation Index Based on the TMPA and CMORPH Precipitation Products for Drought Monitoring in China. IEEE J. Sel. Top. Appl. Earth Obs. Remote Sens. 2018, 11, 1387-1396. [CrossRef]

8. Meschiatti, M.C.; Blain, G.C. Increasing the regional availability of the Standardized Precipitation Index: An operational approach. Bragantiacampinas 2016, 75, 507-521. [CrossRef]

9. Juliani, B.H.T.; Okawa, C.M.P. Application of a Standardized Precipitation Index for meteorological drought analysis of a semi-arid climate influence in Minas Gerais, Brasil. Hydrology 2017, 4, 26. [CrossRef] 
10. Elkollaly, M.; Khadr, M.; Zeidan, B. Drought analysis in the Eastern Nile basin using the standardized precipitation index. Environ. Sci. Pollut. Res. 2018, 25, 30772-30786. [CrossRef]

11. Merabti, A.; Martins, D.S.; Meddi, N.; Pereira, L.S. Spatial and Time Variability of Drought Based on SPI and RDI with Various Time Scales. Water Resour. Manag. 2018, 32, 1087-1100. [CrossRef]

12. Massachusetts Drought Management Task Force, Standardized Precipitation Index (SPI). Available online: https://www.mass.gov/service-details/standardized-precipitation-index-spi (accessed on 13 May 2020).

13. India Meteorological Department, Standardized Precipitation Index. Available online: http://www.imdpune. gov.in/hydrology/hydr_products.html (accessed on 13 May 2020).

14. Vicente-Serrano, S.M.; Beguería, S.; López-Moreno, J.I. A multiscalar drought index sensitive to global warming: The standardized precipitation evapotranspiration index. J Clim. 2010, 23, 1696-1718. [CrossRef]

15. Ward, A.S.; Bejarano, M.D.; Iglesias, A.; Asenjo, V.; Garrote, L. Analysis of Current and Future SPEI Droughts in the La Plata Basin Based on Results from the Regional Eta Climate Model. Water 2017, 9, 857. [CrossRef]

16. Liu, A.; Pan, Y.; Zhu, X.; Yang, T.; Bai, J.; Sun, Z. Drought evolution and its impact on the crop yield in the North China Plain. J. Hydrol. 2018, 564, 984-996. [CrossRef]

17. Mohsenipour, M.; Shahid, S.; Chung, E.; Wang, X. Changing Pattern of Droughts during Cropping Seasons of Bangladesh. Water Resour. Manag. 2018, 32, 1555-1568. [CrossRef]

18. Shukla, S.; Wood, A.W. Use of a standardized runoff index for characterizing hydrologic drought. Geophys. Res. Lett. 2008, 35, L02405. [CrossRef]

19. Pfister, S.; Koehler, A.; Hellweg, S. Assessing the Environmental Impacts of Freshwater Consumption in LCA. Environ. Sci. Technol. 2009, 43, 4098-4104. [CrossRef]

20. Wu, J.; Miao, C.; Tang, X.; Duan, Q.; Heb, X. A nonparametric standardized runoff index for characterizing hydrological drought on the Loess Plateau, China. Glob. Planet. Chang. 2018, 161, 53-65. [CrossRef]

21. Bayissa, Y.; Maskey, S.; Tadesse, T.; van Andel, S.J.; Moges, S.; van Griensven, A.; Solomatine, D. Comparison of the Performance of Six Drought Indices in Characterizing Historical Drought for the Upper Blue Nile Basin, Ethiopia. Geosciences 2018, 8, 81. [CrossRef]

22. Zou, L.; Xia, J.; She, D. Analysis of Impacts of Climate Change and Human Activities on hydrological Drought: A Case Study in the Wei River Basin, China. Water Resour. Manag. 2018, 32, 1421-1438. [CrossRef]

23. Yuan, X.; Zhang, M.; Wang, L.; Zhou, T. Understanding and seasonal forecasting of hydrological drought in the Anthropocene. Hydrol. Earth Syst. Sci. 2018, 21, 5477-5492. [CrossRef]

24. Nilsalab, P.; Gheewala, S.H.; Silalertruksa, T. Methodology development for including environmental water requirement in the water stress index considering the case of Thailand. J Clean. Prod. 2017, 167, 1002-1008. [CrossRef]

25. Ngo, T.T.; Le, N.T.; Hoang, T.M.; Luong, D.H. Water Scarcity in Vietnam: A Point of View on Virtual Water Perspective. Water Resour. Manag. 2018, 32, 3579-3593. [CrossRef]

26. Nilsalab, P.; Gheewala, S.H.; Pfister, S. Method Development for Including Environmental Water Requirement in the Water Stress Index. Water Resour. Manag. 2018, 32, 1585-1598. [CrossRef]

27. Liu, J.; Yang, H.; Gosling, S.N.; Kummu, M.; Flörke, M.; Pfister, S.; Hanasaki, N.; Wada, Y.; Zhang, X.; Zheng, C.; et al. Water scarcity assessments in the past, present, and future. Earth's Future 2017, 5, 545-559. [CrossRef] [PubMed]

28. SOER 2015-The European Environment-State and Outlook 2015-Countries and Regions-Mediterranean Sea Region. Available online: https://www.eea.europa.eu/soer/2015/countries/mediterranean (accessed on 31 May 2020).

29. Contreras, S.; Hunink, J.E. Water accounting at the basin scale: Water use and supply (2000-2010) in the Segura River Basin using the SEEA framework. In Future Water Technical Report $n$. 133; DG-ENV- European Commission: Cartagena, Spain, 2015.

30. De Roo, A.; Bisselink, B.; Beck, H.; Bernhard, J.; Burek, P.; Reynaud, A.; Pastori, M.; Lavalle, C.; Jacobs, C.; Baranzelli, C.; et al. Modelling Water Demand and Availability Scenarios for Current and Future Land Use and Climate in the Sava River Basin; Publications Office of the European Union: Luxembourg, 2016; EUR 27701 EN. [CrossRef]

31. Karabulut, A.; Egoh, B.N.; Lanzanova, D.; Grizzetti, B.; Bidoglio, G.; Pagliero, L.; Bouraoui, F.; Aloe, A.; Reynaud, A.; Maes, J.; et al. Mapping water provisionig services to support the ecosystem-water-food-energy nexus in the Danube river basin. Ecosyst. Serv. 2016, 17, 278-292. [CrossRef] 
32. European Environment Agency. Results and lessons from implementing the Water Assets Accounts in the EEA area. In Technical Report n.7/2013; European Environment Agency: Luxembourg, 2013. [CrossRef]

33. Pedro-Monzonís, M.; Solera, A.; Ferrer, J.; Estrela, T.; Paredes-Arquiola, J. A review of water scarcity and drought indexes in water resources planning and management. J. Hydrol. 2015, 527, 482-493. [CrossRef]

34. Blum, A.G.; Archfield, S.A.; Vogel, R.M. On the probability distribution of daily streamflow in the United States. Hydrol. Earth Syst. Sci. 2017, 21, 3093-3103. [CrossRef]

35. Waseem, M.; Shin, J.Y.; Kim, T.W. Comparing Spatial Interpolation Schemes for Constructing a Flow Duration Curve in an Ungauged Basin. Water Resour. Manag. 2015, 29, 2249-2265. [CrossRef]

36. Atieh, M.; Gharabaghi, B.; Rudra, R. Entropy-based neural networks model for flow duration curves at ungauged sites. J. Hydrol. 2015, 529, 1007-1020. [CrossRef]

37. Longobardi, A.; Villani, P. A statistical, parsimonious, empirical framework for regional flow duration curve shape prediction in high permeability Mediterranean region. J. Hydrol. 2013, 507, 174-185. [CrossRef]

38. Ziolkowska, J.R.; Ziolkowski, B. Effectiveness of Water Management in Europe in the 21st Century. Water Resour. Manag. 2016, 30, 2261-2274. [CrossRef]

39. Santato, S.; Mysiak, J.; Pérez-Blanco, C.D. The Water Abstraction License Regime in Italy: A Case for Reform? Water 2016, 8, 103. [CrossRef]

40. European Environment Agency. The European Environment State and Outlook 2015: Synthesis Report; European Environment Agency: Copenhagen, Denmark; Publications Office of the European Union: Luxembourg, 2015. [CrossRef]

41. Delipetrev, B.; Jonoski, A.; Solomatine, D.P. Development of a web application for water resources based on open source software. Comput. Geosci. 2014, 62, 35-42. [CrossRef]

42. Casadei, S.; Pierleoni, A.; Bellezza, M. Sustainability of Water Withdrawals in the Tiber River Basin (Central Italy). Sustainability 2018, 10, 485. [CrossRef]

43. Nash, J.E.; Sutcliffe, J.V. River flow forecasting through conceptual models part I-A discussion of principles. J. Hydrol. 1970, 10, 282-290. [CrossRef]

44. Linoli, A. Physical, agricultural and economic Italy today. In Land Reclamation, Irrigation and Flood Protection in Italy over the Centuries; ITAL-ICID; Italian Committee for Irrigation and Drainage: Rome, Italy, 2006.

45. L'vovich, M.I. Hydrologic budget of continents and estimate of the balance of global fresh water resources. Sov. Hydrol. 1972, 4, 349-360.

46. Casadei, S. Base flow index analysis of some hydrographic basins in Central Italy. Idrotecnica 1995, 3, 177-191. (In Italian)

47. Boni, C.; Bono, P.; Cappelli, G. Hydrogeological Map. In Hydrogeological Scheme of Central Italy; Italian National Research Council, Sapienza University of Rome: Rome, Italy, 1987.

48. Manciola, P.; Casadei, S. Low flow index and hydrogeological characteristics. In Proceedings of the National Conference in Hydraulic Engineering-ASCE, Nashville, TN, USA, 29 July-2 August 1991.

49. Vogel, R.M.; Fennessey, N.M. Flow duration curves. I: New interpretation and confidence intervals. J. Water Resour. Plan. Manag. 1994, ASCE 120, 485-504. [CrossRef]

50. León, D.G.; Standardi, G.; Staccione, A. An integrated approach for the estimation of agricultural drought costs. Land Use Policy 2021, 100, 1-10. [CrossRef]

51. European Environment Agency. Water Exploitation Index Plus (WEI ${ }^{+}$) for River Basin Districts (2002-2014) GIS Map Application before October 2018. Available online: https://www.eea.europa.eu/data-and-maps/ explore-interactive-maps/water-exploitation-index-for-river-1 (accessed on 22 August 2018).

52. European Environment Agency. Water Exploitation Index Plus (WEI ${ }^{+}$) for River Basin Districts (1990-2015) GIS Map Application Published 10 Oct 2018 Last Modified 28 Nov 2019. Available online: https://www. eea.europa.eu/data-and-maps/explore-interactive-maps/water-exploitation-index-for-river-2 (accessed on 29 January 2020).

Publisher's Note: MDPI stays neutral with regard to jurisdictional claims in published maps and institutional affiliations. 